\title{
IMPLEMENTASI UNDANG-UNDANG NOMOR 1 TAHUN 1974 TENTANG IZIN POLIGAMI DI PENGADILAN AGAMA BUKITTINGGI (STUDI KASUS PERKARA NOMOR 081/PDT.G/2013/PA.BKT DAN PERKARA NOMOR 0328/PDT.G.2015/PA.BKT)
}

\author{
Setia Handayani \\ IAIN Bukittinggi, setiahandayani@gmail.com \\ Aidil Alfin \\ LAIN Bukittinggi, aidilalfin@gmail.com \\ Dahyul Daipon \\ IAIN Bukittinggi,dabyul_daipon@gmail.com
}

\begin{tabular}{l|l|l} 
Diterima: 15Januari 2019 & Direvisi : 11 Mei 2019 & Diterbitkan: 30 Juni 2019
\end{tabular}

\begin{abstract}
The provision of polygamy as regulated in Law Number 1 of 1974 states that a busband who is going to polygamy must meet alternative and cumulative requirements. Without the fulfillment of the two conditions mentioned, the application for polygamy will be rejected by the judge. But in reality, the Bukittinggi Religious Court differed in ruling two polygamy cases which both met cumulative requirements and did not meet alternative conditions. In the first case case Number 081 / Pdt.G / 2013 / PA.Bkt the judge has accepted the request for polygamy, while in the second case case Number 0328 / Pdt.G / 2015 / PA.Bkt. the judge did not accept (NO) the case. The implementation of Law Number 1 of 1974 concerning polygamy permits in the Bukittinggi Religious Court is not absolute, the consideration of judges who receive and examine cases Number 081 / Pdt.G / 2013 / PA.Bkt is the emergence of mudharat if the case is rejected even though the alternative conditions are not met. Whereas the judge examining case 0328 / Pdt.G / 2015 / PA.Bkt was based on the provisions of article 4 of Law Number 1 of 1974 rejecting the case because it did not meet alternative conditions. Due to the non-fulfillment of alternative conditions by the Petitioner, the request for polygamy permit had a formal defect. For this reason, the panel of judges no longer needs to examine the subject matter.
\end{abstract}

Keyword: Poligamy, Alternative Terms, Cumulative Terms, Indonesian Contitution No. 1/1974.

\begin{abstract}
Abstrak
Ketentuan poligami sebagaimana di atur dalam Undang-Undang Nomor 1 Tabun 1974 menyatakan bahwa seorang suami yang akan berpoligami harus memenubi persyaratan alternatif dan persyaratan kumulatif. Tanpa terpenubi kedua syarat dimaksud, maka permohonan poligami akan ditolak oleh hakim. Namun dalam kenyataannya, Pengadilan Agama Bukittinggi berbeda dalam memutuskan dua perkara poligami yang keduanya sama-sama memenubi syarat kumulatif dan tidak memenubi syarat alternatif. Dalam kasus pertama perkara Nomor 081/Pdt.G/2013/PA.Bkt hakim telah menerima permohonan poligami, sedangkan dalam kasus kedua perkara Nomor 0328/Pdt.G/2015/PA.Bkt. hakim tidak menerima (NO) perkara tersebut. Implementasi Undang-Undang Nomor 1 Tahun 1974 tentang izin poligami di Pengadilan Agama Bukittinggi tidak bersifat mutlak, pertimbangan hakim yang menerima dan memeriksa perkara Nomor 081/Pdt.G/2013/PA.Bkt adalah timbulnya mudharat jika perkara tersebut ditolak walaupun syarat alternatif tidak terpenubi. Sedangkan hakim yang memeriksa perkara 0328/Pdt.G/2015/PA.Bkt berlandaskan pada ketentuan pasal 4 Undang-Undang Nomor 1 Tabun 1974 menolak perkara tersebut karena tidak memenubi syarat alternatif. Karena tidak terpenubinya syarat alternatif oleh Pemohon maka permohonan izin poligami mengalami cacat formil. Untuk itu majelis hakim tidak perlu lagi memeriksa pokok perkara tersebut.
\end{abstract}

Kata Kunci: Poligami, Syarat Alternatif, Syarat Kumulatif, Undang-Undang Nomor 1 tahun 1974. 


\section{PENDAHULUAN}

Pernikahan atau perkawinan merupakan sunatullah, hukum Allah di dunia dan juga salah satu sunnah Nabi yang harus dilaksanakan oleh setiap umatnya, baik laki-laki maupun perempuan, baik itu kaya maupun miskin. Dengan perkawinan timbulah rasa kasih sayang antara laki-laki dan perempuan sehingga dapat meneruskan keturunan antara keduanya. Hal ini tergambar dalam Alquran surat ar-Rum ayat 21. Sedangkan dalam Undang-Undang Nomor 1 Tahun 1974 Bab I Pasal I, perkawinan adalah ikatan lahir batin antara seorang pria dengan seorang wanita sebagai suami istri dengan tujuan membentuk keluarga (rumah tangga) yang bahagia dan kekal berdasarkan Ketuhanan Yang Maha Esa. ${ }^{1}$ Definisi yang diberikan oleh Undang-Undang Nomor 1 Tahun 1974 tersebut mengisyaratkan bahwa perkawinan dilakukan dengan tujuan bahagia, baik kebahagiaan suami maupun kebahagiaan istri sebagai pendamping suami dalam rumah tangga maupun kehidupan masyarakat. Dari kata kekal dalam pasal tersebut dapat diartikan bahwa perkawinan dilakukan sekali seumur hidup.

Dari pengertian perkawinan di atas, dapat ditarik kesimpulan bahwa prinsip dari suatu perkawinan menurut Undang-Undang Nomor 1 Tahun 1974 adalah; tujuan perkawinan adalah membentuk keluarga yang bahagia dan kekal; sahnya perkawinan sangat tergantung pada ketentuan hukum agama dan kepercayaan masing-masing; asas monogami; calon suami dan istri harus telah dewasa jiwa dan raganya; mempersulit terjadinya perceraian; hak dan kedudukan suami istri adalah seimbang. ${ }^{2}$

1 Undang-Undang Republik Indonesia Nomor 1 Tabun 1974 tentang Perkawinan dan Kompilasi Hukum Islam, Cetakan I, (Jakarta: Grahamedia Press, 2014), 2

2 Amir Nuruddin dan Azhari Akmal Tarigan, Hukum Perdata Islam di Indonesia, Jakarta: Kencana, 2004), 54
Salah satu prinsip perkawinan adalah menganut asas monogami, berarti seorang suami hanya boleh mempunyai seorang istri dan seorang istri hanya boleh memiliki seorang suami. Lawan kata dari monogami adalah poligami. Kata poligami berasal dari bahasa Yunani, polus yang artinya banyak dan gamein yang artinya kawin. Jadi, poligami berarti suami beristri banyak pada waktu yang sama. ${ }^{3}$

Kebolehan berpoligami dalam Islam terdapat dalam Q.S An-Nisa' ayat 3. Namun di Indonesia kebolehan tersebut harus memenuhi syarat sesuai dengan yang diatur dalam Undang-Undang Nomor 1 Tahun 1974 tentang Perkawinan, khususnya pasal 4 dan 5. Pada pasal 4 disebutkan, seorang suami yang akan beristri lebih dari seorang apabila: ${ }^{4}$ Istri tidak dapat menjalankan kewajibannya sebagai istri; Istri mendapat cacat badan atau penyakit yang tidak dapat disembuhkan; Istri tidak dapat melahirkan keturunan. Selain itu pada pasal 5 juga dinyatakan, syarat-syarat yang harus dipenuhi seorang suami yang ingin melakukan poligami adalah: ${ }^{5}$ Adanya persetujuan dari istri/istri-istri; Adanya kepastian bahwa suami mampu menjamin keperluan-keperluan hidup istri-istri dan anakanak mereka; Adanya jaminan bahwa suami akan berlaku adil terhadap istri-istri dan anakanak mereka.

Untuk membedakan persyaratan yang ada dalam pasal 4 dan 5 tersebut adalah, pada pasal 4 disebut dengan persyaratan alternatif yang artinya salah satu harus ada untuk dapat mengajukan permohonan poligami. Sedangkan pasal 5 adalah persyaratan kumulatif di mana seluruhnya harus dapat dipenuhi suami yang akan melakukan poligami. ${ }^{6}$

\footnotetext{
3 Beni Ahmad Saebani, Figh Munakahat 2, (Bandung: CV Pustaka Setia, 2001), 151

4 Undang-Undang Republik Indonesia Nomor 1 Tahun $1974 \ldots ., 2$

${ }^{5}$ Ibid.

${ }^{6}$ Amir Nuruddin dan Azhari Akmal Tarigan, Hukum Perdata Islam di Indonesia, (Jakarta: Kencana, 2004), 164
} 
Berdasarkan realita yang ditemukan di lapangan, khususnya di Pengadilan Agama Bukittinggi, ada dua putusan yang berbeda dalam memeriksa permohonan izin poligami oleh hakim padahal karakteristik kedua perkara itu identik, yaitu sama-sama memenuhi persyaratan kumulatif dan tidak terpenuhi syarat alternatif. Perkara dengan nomor 081/Pdt.G/2013/PA.Bkt dikabulkan oleh hakim artinya Pemohon diberi izin untuk melakukan poligami walaupun syarat alternatif tidak terpenuhi. Sedangkan perkara nomor 0328/Pdt.G/2015/PA.Bkt tidak diterima (Niet onvankelijke verklaard/NO) padahal juga tidak memenuhi syarat alternatif pada pasal 4 Undang-Undang Nomor 1 Tahun 1974.

Untuk mengetahui fakta yang sebenarnya terjadi, maka penulis ingin mengetahui tentang implementasi UndangUndang Nomor 1 Tahun 1974 tentang izin poligami di Pengadilan Agama Bukittinggi dan pertimbangan hakim dalam memutuskan perkara izin poligami di Pengadilan Agama Bukittinggi.

\section{METODE PENELITIAN}

Artikel ini adalah hasil dari penelitian ini merupakan penelitian lapangan (field research), yaitu kegiatan penelitian yang dilakukan di lingkungan masyarakat tertentu baik di lembaga-lembaga organisasi masyarakat (sosial) maupun lembaga pemerintahan. ${ }^{7}$ Kemudian Kegiatan penelitian ini dilakukan dengan menghimpun data dari berbagai literatur, baik di perpustakaan maupun di tempat-tempat lain. Literatur yang digunakan tidak terbatas hanya pada buku-buku tetapi juga berupa bahan-bahan dokumentasi, majalah-majalah, koran-koran, dan lain-lain. ${ }^{8}$

Karena objek penelitian ini studi lapangan, maka penulis berusaha mencari informan yang terkait dengan masalah.

\footnotetext{
7 Sumardi Suryabrata, Metodologi Penelitian, (Jakarta: PT Raja Grafindo Persada, 1998), 22

8 Mahmud, Metode Penelitian Pendidikan, (Bandung: Pustaka Setia, 2011), 31
}

Adapun informan yang menjadi sumber data pada tulisan ini adalah tentunya pihak Pengadilan Agama Bukittinggi terkhususnya hakim yang memutuskan kedua perkara tersebut. Dalam mengumpulkan data, penulis menggunakan beberapa metode, yaitu; wawancara dan dokumentasi.

Dalam menyajikan data, penulis menyajikan data dalam bentuk deskriptif, yaitu menggambarkan fakta-fakta dan data-data yang diperoleh dengan menggunakan kalimat dalam bentuk pragraf. Setelah itu baru dilakukan penarikan kesimpulan.

\section{POLIGAMI DALAM ISLAM}

Kata poligami, secara etimologi berasal dari bahasa Yunani, yaitu polus yang berarti banyak dan gamos yang berarti perkawinan. Bila kata ini digabungkan, maka poligami akan berarti suatu perkawinan yang banyak atau lebih dari seorang. Dalam bahasa Arab, poligami disebut dengan ta'did al-zawjah (berbilangnya pasangan). Menurut ajaran Islam, yang kemudian disebut dengan syari'at islam (hukum Islam), poligami ditetapkan sebagai perbuatan yang dibolehkan atau mubah. Dengan demikian, meskipun dalam surat An-Nisa' ayat 3 disebutkan kalimat "fankibu", kalimat amr (perintah) tersebut berfaedah mubah bukan wajib, yang dapat direlevansikan dengan kaidah ushul fiqh: al-asl fi al-amr al-ibadah hatta yadula dalilu 'ala at-tahrim (asal dari sesuatu itu boleh, kecuali ada dalil yang mengharamkannya). ${ }^{9}$

Poligami memiliki akar sejarah yang cukup panjang, sepanjang sejarah peradaban manusia itu sendiri. Sebelum Islam datang ke Jazirah Arab, poligami merupakan sesuatu yang telah mentradisi bagi masyarakat Arab. Poligami masa itu dapat disebut poligami tak terbatas. Lebih dari itu tidak ada gagasan keadilan di antara para istri. Suamilah yang menentukan sepenuhnya siapa yang paling ia

9 Beni Ahmad Saebani, Figh Munakahat 2, (Bandung: Pustaka Setia, 2001), 151 
sukai dan siapa yang ia pilih untuk dimiliki secara tidak terbatas. Para istri harus menerima takdir mereka tanpa ada usaha untuk memperoleh keadilan. ${ }^{10}$

Ketika Islam datang dan menyebar di dunia Arab, ada beberapa orang Arab yang memiliki istri sampai sepuluh. Seperti Ghailan, ketika masuk Islam, dia memiliki istri sepuluh, kemudian Rasulullah SAW menyuruhnya untuk memilih empat dari mereka dan menceraikan yang lain. Begitu juga Qais bin alHarits al-Asadi yang memiliki istri delapan, ketika masuk Islam Rasulullah SAW menyuruhnya untuk memilih empat dari mereka dan menceraikan yang lainnya. ${ }^{11}$

Setelah Islam datang parktik poligami tetap dibolehkan hanya saja seorang suami yang hendak poligami dibatasi maksimal memiliki 4 orang istri. Selain itu suami tersebut juga mampu berlaku adil terhadap istri-istrinya. Dan hal demikian diatur oleh Allah di dalam Alquran dan juga ditegaskan dalam Hadis Nabi SAW.

Secara konkrit Islam tidak membahas hukum poligami dan tidak mensyariatkan paraktiknya kepada para pengikutnya. Realitas poligami telah berlansung dalam kehidupan umat serta masyarakat terdahulu, juga berlansung di dalam lingkungan pemeluk agama Samawi yang lain, dan tradisi masyarakat Arab Jahiliyah, akan tetapi belum terdapat dalam realitas kehidupan mereka batasan-batasan yang benar serta panduan hukum yang baik terhadap praktik ini.

Allah SWT membolehkan berpoligami sampai empat orang istri dengan syarat berlaku adil kepada mereka. Yaitu adil dalam melayani istri, seperti urusan nafkah, tempat tinggal, pakaian, giliran dan segala hal yang bersifat lahiriah. Jika tidak bisa berlaku adil maka cukup satu istri saja (monogami). ${ }^{12}$

\footnotetext{
10 Amir Nuruddin dan Azhari Akmal Tarigan, Hukum Perdata Islam di Indonesia, 157

${ }^{11}$ Karim Ilmi Farhat Ahmad, Ta'addu az-Zaujat fi al-Adyan, (Dar al-Afaq al-'Arabiyyah, 2007), 14

12 Abdul Rahman Ghozali, Figh Munakahat,
}

Hal ini didasarkan pada firman Allah surat AnNisa' ayat (3) :

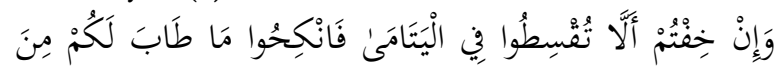

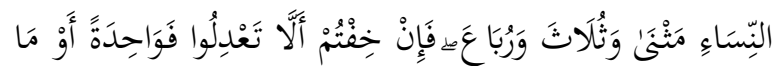

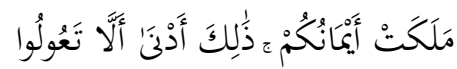

"Dan jikea kamu takut tidak akan dapat Berlaku adil terbadap (bak-bak) perempuan yang yatim (bilamana kamu mengawininya), Maka kawinilah wanita-wanita (lain) yang kamu senangi : dua, tiga atau empat. kemudian jikea kamu takut tidak akan dapat Berlaku adil, Maka (kawinilah) seorang saja, atau budak-budak yang kamu miliki. yang demikian itu adalah lebih dekat kepada tidak berbuat aniaya."

Merujuk pada ayat di atas, maka pelaksanaan poligami diatur dengan prinsipprinsip kemanusiaan dan keadilan terbesar. Oleh karena itu, para ulama dan fuqaha telah menetapkan persyaratan di bawah ini apabila seorang lelaki muslim hendak menikah lebih dari seorang istri: $^{13}$ Seorang lelaki harus memiliki kemampuan dana yang cukup untuk membiayai berbagai keperluan dengan bertambahnya istri yang dinikahi, dan seorang lelaki harus memperlakukan semua istrinya dengan adil. Tiap istri harus diperlakukan sama dalam memenuhi hak perkawinan serta hakhak yang lain.

Seorang laki-laki yang akan melakukan poligami adalah orang yang mampu dalam hal materi yaitu uang. Karena dia akan menafkahi lebih dari satu orang, maka perlu materi yang cukup agar istri-istri nya hidup layak. Sedangkan maksud poin b adalah seorang suami yang melakukan poligami harus adil terhadap semua istri-istrinya. Karena tujuan perkawinan adalah membentuk keluarga yang bahagia, maka jangan sampai poligami menghancurkan hakikat dari sebuah perkawinan. Kalau sekiranya suami tidak akan mampu berbuat adil maka cukup menikahi satu perempuan saja sesuai ayat ke 3 dari surat

(Jakarta: Kencana, 2010), 129

13 A. Rahman I. Doi, Penjelasan Lengkeap Hukum-Hukum Allah (Syari'ab), (Jakarta: Rajawali Pers, 2002), 192 
An-Nisa' sebelumnya.

Suami harus adil terhadap istri-istrinya dalam hal materi seperti pangan, pakaian, tempat tinggal, dan membagi giliran pada masing-masing istri, tanpa membedakan antara istri yang kaya dengan istri yang miskin, yang berasal dari keturunan tinggi dengan yang berasal dari golongan bawah.

Mengenai adil terhadap istri-istri dalam masalah cinta dan kasih sayang, Abu Bakar bin Araby mengatakan bahwa hal ini berada di luar kesanggupan manusia, sebab cinta itu adanya dalam genggaman Allah SWT yang mampu membolak-balikkannya menurut kehendakNya. Begitu pula dengan hubungan seksual, terkadang suami bergairah dengan istri yang satu, tetapi tidak bergairah dengan istri lainnya. ${ }^{14}$

Sesuai firman Allah dalam surat An-Nisa' ayat (129):

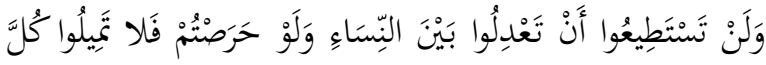

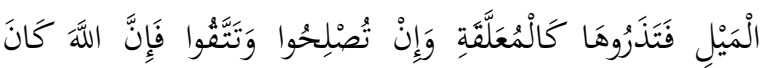

$$
\begin{aligned}
& \text { غَفْورًا رَحِيمًا }
\end{aligned}
$$

"Dan kamu sekali-kali tidak akan dapat Berlaku adil di antara isteri-isteri(mu), walaupun kamu sangat ingin berbuat demikian, karena itu janganlah kamu terlalu cenderung (kepada yang kamu cintai), sehingga kamu biarkan yang lain terkatung-katung. dan jika kamu Mengadakan perbaikan dan memelihara diri (dari kecurangan), Maka Sesunggubnya Allab Maba Pengampun lagi Maba Penyayang."

Selain ketentuan adil dan mampu yang harus dimiliki oleh seorang suami yang akan melakukan poligami dalam surat An-Nisa' ayat 3, ketentuan lain tentang syarat poligami adalah batas poligami dengan jumlah maksimal empat (ruba'a) orang istri.

Dari penjelasan di atas dapat ditarik kesimpulan bahwa yang menjadi syarat seseorang untuk berpoligami berdasarkan ayat Alquran adalah; Mampu berbuat adil kepada semua istrinya (An-Nisa': 3); mampu menjaga

14 Slamet Abidin dan Aminuddin, Fiqh Munakahat, (Bandung: CV. Pustaka Setia, 1999), $136-$ 137 diri untuk tidak terperdaya dengan istri-istrinya itu dan tidak meninggalkan hak-hak Allah karena keberadaan mereka (At-Tagabun: 14); memiliki kemampuan untuk memenuhi kebutuhan-kebutuhan lahiriah dan menjaga kehormatan mereka, hal ini bertujuan agar istri-istrinya itu terhindar dari kenistaan dan kerusakan, karena Allah tidak menyukai kerusakan; memiliki kesanggupan untuk memberi nafkah kepada mereka (An-Nur: 33); batasan poligami maksimal 4 orang istri (AnNisa': 3).

\section{POLIGAMI DALAM PERSPEKTIF HUKUM POSITIF INDONESIA}

Dasar hukum poligami dalam hukum positif Indonesia dapat kita lihat di dalam Undang-Undang No.1 Tahun 1974 tentang Perkawinan pasal 4 dan 5 jo Kompilasi Hukum Islam (KHI) pasal 55-59.

Dalam Pasal 3 UU Perkawinan ini sebenarnya menganut asas monogami, yaitu seorang pria hanya boleh mempunyai seorang istri dan seorang perempuan hanya boleh mempunyai seorang suami. Namun pada pasal selanjutnya yaitu Pasal 4 dan 5 menyatakan dalam keadaan tertentu poligami itu dibenarkan, artinya seorang laki-laki boleh menikahi lebih dari satu orang wanita.

Klausul kebolehan poligami di dalam UU Perkawinan sebenarnya hanyalah pengecualian dan untuk itu pasal-pasalnya mencamtumkan alasan-alasan yang membolehkan tersebut.

Dalam pasal 4 UU Perkawinan dinyatakan bahwa dalam hal seorang suami akan beristri lebih dari seorang, sebagaimana tersebut dalam Pasal 3 ayat (2) UndangUndang ini, maka ia wajib mengajukan permohonann kepada Pengadilan di daerah tempat tinggalnya. ${ }^{15}$

Pengadilan dimaksud data ayat (1) pasal ini hanya memberikan izin kepada seorang

15 Undang-Undang Republik Indonesia Nomor 1 Tabun $1974 \ldots, 2$ 
suami yang akan beristri lebih dari seorang apabila; Istri tidak dapat menjalankan kewajibannya sebagai istri; Istri mendapat cacat badan atau penyakit yang tidak dapat disembuhkan; dan Istri tidak dapat melahirkan keturunan.

Dengan adanya pasal-pasal yang membolehkan untuk berpoligami kendatipun dengan alasan-alasan tertentu, jelaslah bahwa asas yang dianut oleh Undang-Undang Perkawinan bukan asas monogami mutlak melainkan monogami terbuka. Poligami ditempatkan pada status hukum darurat (emergency law), atau dalam keadaan yang luar biasa (extra ordinary circumstance). Di samping itu lembaga poligami tidak semata-mata kewenangan penuh suami tetapi atas dasar izin dari hakim (pengadilan). ${ }^{16}$

Selain syarat yang terdapat dalam Pasal 4, pada Pasal 5 juga dijelaskan mengenai syarat kebolehan poligami, yaitu Untuk dapat mengajukan permohonan kepada Pengadilan, sebagaimana dimaksud dalam Pasal 4 ayat (1) Undang-Undang ini, harus dipenuhi syaratsyarat; Adanya persetujuan dari istri/istri-istri; Adanya kepastian bahwa suami mampu menjamin keperluan-keperluan hidup istri-istri dan anak-anak mereka; Adanya jaminan bahwa suami akan berlaku adil terhadap istri-istri dan anak-anak mereka. ${ }^{17}$

Persetujuan yang dimaksud, tidak diperlukan bagi seorang suami apabila istri/istri-istrinya tidakmungkin dimintai persetujuannya dan tidak dapat menjadi pihak dalam perjanjian, atau apabila tidak ada kabar dari istrinya selama sekurang-kurangnya 2 (dua) tahun, atau karena sebab-sebab lainnya yang perlu mendapat penilaian dari Hakim Pengadilan.

Dalam penjelasan lebih lanjut, PP No. 9 Tahun 1975 tentang Pelaksanaan UU No. 1 tahun 1974 menerangkan dalam pasal 40, 41,

\footnotetext{
16 Yahya Harahap, Hukum Perkawinan Nasional, (Medan: Zahir Trading Co Medan, 1975), 25-26

17 Undang-Undang Republik Indonesia Nomor 1 Tahun $1974 \ldots, 2-3$
}

42, 43 dan pasal 44. Dalam pasal 40 berbicara mengenai "apabila seorang suami bermaksud untuk beristri lebih dari seorang maka ia wajib mengajukan permohonan secara tertulis kepada pengadilan" dan pada pasal 41 pengadilan kemudian memeriksa mengenai:

1. Ada atau tidaknya alasan yang memungkinkan seorang suami kawin lagi

2. Ada atau tidaknya persetujuan dari istri, baik persetujuan lisan maupun tertulis, apabila persetujuan itu merupakan persetujuan lisan, persetujuan itu harus diucapkan di depan sidang pengadilan.

3. Ada atau tidak adanya jaminan bahwa suami akan berlaku adil terhadap istri-istri ana anak-anak mereka dengan pernyataan atau janji dari suami yang dibuat dalam bentuk yang ditetapkan untuk itu.

Pasal 43 menerangkan apabila pengadilan berpendapat bahwa cukup alasan bagi pemohon untuk beristri lebih dari seorang, maka Pengadilan memberikan putusannya yang berupa izin untuk beristri lebih dari seorang dan pasal 44 menerangkan bahwa pegawai Pencatat dilarang untuk melakukan pencatatan perkawinan seorang suami yang akan beristri lebih dari seorang sebelum adanya izin Pengadilan seperti yang dimaksud dalam pasal 43.

Selain Undang-Undang Nomor 1 Tahun 1974, Kompilasi Hukum Islam juga mengatur tentang poligami. KHI memuat masalah poligami ini pada bagian IX dengan judul "Beristri lebih dari satu orang" yang diungkapkan dari pasal 55 sampai pasal 59. Pada pasal 55 dinyatakan; Beristri lebih dari satu orang pada waktu bersamaan, terbatas hanya sampai empat orang istri; Syarat utama beristri lebih dari satu orang, suami harus mampu berlaku adil terhadap istri-istri dan anak-anaknya; Apabila syarat utama yang disebut pada ayat (2) tidak mungkin dipenuhi, suami dilarang beristri lebih dari satu orang.

Lebih lanjut dalam pasal 56 dijelaskan bahwa; Suami yang hendak beristri lebih dari satu orang harus mendapat izin dari Pengadilan Agama; Pengajuan permohonan 
izin dimaksudkan pada ayat 1 dilakukan Menurut tata cara sebagaimana siatur dalam Bab VIII PP No. 9 Tahun 1975; Perkawinan yang dilakukan dengan istri kedua, ketiga atau keempat tanpa izin dari Pengadilan Agama, tidak mempunyai kekuatan hukum.

Pada pasal 57 dijelaskan bahwa Pengadilan Agama hanya memberi izin kepada suami yang akan beristri lebih dari seorang apabila; Istri tidak dapat menjalankan kewajiban sebagai istri; Istri mendapat cacat badan atau penyakit yang tidak dapat disembuhkan; Istri tidak dapat melahirkan keturunan.

Tampak pada pasal 57, Pengadilan Agama hanya memberikan izin kepada suami yang akan beristri lebih dari seorang apabila terdapat alasan-alasan sebagaimana disebut dalam pasal 4 Undang-Undang Perkawinan. Jadi pada dasarnya pengadilan dapat memberi izin kepada seorang suami untuk beristri lebih dari seorang apabila dikehendaki oleh pihakpihak yang bersangkutan. ${ }^{18}$

Selanjutnya pada pasal 59 juga dijelaskan bahwa dalam hal istri tidak mau memberikan persetujuan, dan permohonan izin untuk beristri lebih dari satu orang berdasarkan atas salah satu alasan yang diatur dalam pasal 55 ayat (2) dan 57, Pengadilan Agama dapat menetapkan tentang pemberian izin setelah memeriksa dan mendengar istri yang bersangkutan di persidangan Pengadilan Agama, dan terhadap penetapan ini istri atau suami dapat mengajukan banding atau kasasi.

Dari penjelasan di atas dapat disimpulkan bahwa Perundang-undangan Perkawinan Indonesia tentang Poligami sebenarnya telah berusaha mengatur agar lakilaki yang melakukan poligami adalah laki-laki yang benar: (1) mampu secara ekonomi menghidupi dan mencukupi seluruh kebutuhan (sandang-pangan-papan) keluarga (istri-istri dan anak-anak), serta (2) mampu

18 Ahmad Rafiq, Hukum Islam di Indonesia, (Jakarta: Rajawali Pers. 1998), 175 berlaku adil terhadap istri-istri dan anak-anak dari suami poligami tidak disia-siakan. Demikian juga perundang-undangan Indonesia terlihat berusaha menghargai istri sebagai pasangan hidup suami. Terbukti, bagi suami yang akan melaksanakan poligami, suami harus terlebih dahulu mendapatkan persetujuan para istri. $^{19}$

\section{IMPLEMENTASI UU NO.1 TAHUN 1974 TENTANG IZIN POLIGAMI DAN PERTIMBANGAN HAKIM DALAM MENETAPKAN IZIN POLIGAMI DI PENGADILAN AGAMA BUKITTINGGI}

Izin poligami adalah permohonan yang diajukan oleh suami untuk bisa mendapatkan izin dari Pengadilan Agama untuk melakukan poligami. Suami harus membuat surat permohonan yang berisikan alasan-alasan atau dalil-dalil yang menyebabkannya melakukan poligami. ${ }^{20}$ Setelah Pemohon mengajukan permohonannya ke Pengadilan Agama selanjutnya pihak Pengadilan Agama akan memeriksa surat permohonan tersebut terkait dengan alasan-alasan Pemohon apakah sudah memenuhi syarat di dalam Undang-Undang Nomor 1 Tahun 1974 terkait pasal 4 ayat (2) dan 5 ayat (1).

Selain memperhatikan syarat yang ada dalam Undang-Undang Nomor 1 Tahun 1974 pasal 4 dan 5, hakim juga mempertimbangkan dengan syarat yang tercantum dalam Kompilasi Hukum Islam pasal 55 sampai dengan pasal 59.

Pada pasal 55 dinyatakan bahwa Beristri lebih dari satu orang pada waktu bersamaan, terbatas hanya sampai empat orang istri; Syarat utama beristri lebih dari satu orang, suami harus mampu berlaku adil terhadap istri-istri dan anak-anaknya; dan Apabila syarat utama

19 Khairuddin Nasution, Status Wanita di Asia Tenggara; Studi terhadap Perundang-undangan Perkawinan Muslim Kontemporer di Indonesia dan Malaysia, Jakarta: INIS, 2002), 111

20 Martias, Hakim Pengadilan Agama Bukittinggi, Wawancara, Jum'at, 12 Januari 2018, Pukul 09.00 WIB 
yang disebut pada ayat (2) tidak mungkin dipenuhi, suami dilarang beristri lebih dari satu orang.

Menurut pasal 55 Kompilasi Hukum Islam yang menjadi syarat utama bagi suami yang akan berpoligami adalah adil, dan adil disini bisa dilihat dari yang zahir saja seperti materi dan membagi giliran di antara istri-istri. Hal tersebut sesuai dengan Alquran Surat AnNisa' ayat 3. Pengadilan Agama dapat menilai suami bisa berlaku adil dari surat pernyataan yang ditulis oleh yang bersangkutan di atas materai dan diketahui oleh Wali Nagari/Lurah setempat. ${ }^{21}$

Dalam memutuskan permohonan izin poligami hakim mengambil dasar dalam Undang-Undang Nomor 1 Tahun 1974 dan juga Kompilasi Hukum Islam. Jadi, hakim tidak mutlak hanya mengambil dasar pada Undang-Undang Nomor 1 Tahun 1974 saja, tetapi juga dengan mengambil ketentuan yang ada dalam Kompilasi Hukum Islam terkait dengan syarat izin poligami tersebut. Selain itu hakim juga bebas berpendapat di luar ketentuan kedua aturan tersebut, karena pada hakikatnya hakim itu juga pembuat UndangUndang, bukan saja sebagai corong UndangUndang. ${ }^{22}$

\section{Kasus Perkara No.081/Pdt.G/2013/PA.Bkt}

Adapun yang menjadi alasan Pemohon untuk melakukan poligami karena antara Pemohon dan calon istrinya berkenalan sejak tahun 2008, sehingga antara Pemohon dan calon istrinya tersebut telah tertanam rasa cinta yakni saling menyukai. Dan dalam kesehariannya, Pemohon sering bersama dengan calon istrinya tersebut sehingga Pemohon takut jika antara Pemohon dan calon istrinya akan melakukan hal-hal yang diharamkan oleh Allah. Di samping itu Pemohon juga memiliki maksud untuk mencegah dan menghindari fitnah terhadap

21 Ibid.

22 Ibid. diri Pemohon dengan calon istrinya tersebut.

Bahwa keinginan Pemohon untuk berpoligami telah mendapat persetujuan dari istrinya (Termohon) dan juga diizinkan. Pemohon juga menyatakan kesanggupannya untuk berlaku adil dan kesanggupannya menafkahi dua orang istri dan anak-anaknya kelak. Bersarkan alasan tersebut Pemohon memohon agar diberi izin untuk menikah untuk kedua kalinya (poligami) dengan wanita lain (calon istrinya).

Bahwa majelis hakim telah berusaha menasehati pemohon agar mengurungkan niatnya untuk berpoligami karena beratnya beban yang akan ditanggung oleh pemohon dalam menjalani poligami nantinya, namun upaya tersebut tidak berhasil. Alasan pokok diajukan permohonan pemohon adalah pemohon mengajukan izin poligami dengan perempuan bernama $\mathrm{Sw}$ yang saat ini berstatus sebagai janda, karena pemohon sudah punya hubungan dekat dengan Sw semenjak empat tahun yang lalu, dan sudah saling mencintai dan tidak mungkin untuk dipisahkan, antara In dan Sw telah sepakat untuk menikah dan termohon telah memberikan izin kepada pemohon untuk menikah lagi. Dalam persidangan termohon telah memberikan jawabannya yang pada pokoknya menyatakan telah mengetahui pemohon akan menikah dengan seorang perempuan bernama $\mathrm{Sw}$, dan termohon telah memberi izin kepada pemohon sebagai suaminya untuk menikah lagi dengan Sw dan juga menyatakan kesediaan untuk dimadu.

Dalam persidangan majelis hakim telah mendengarkan pernyataan $\mathrm{Sw}$ tentang kesediaannya untuk menikah dengan In dan tidak keberatan untuk menjadi istri yang kedua. Bahwa untuk menguatkan dalil-dalil dan alasan permohonan pemohon, pemohon telah mengajukan alat-alat bukti tertulis sebagai berikut: Fotokopi kutipan akta nikah atas nama pemohon dan termohon yang dikeluarkan oleh PPN/KUA yang berwenang; 
Asli surat pernyataan pemohon untuk berlaku adil terhadap termohon selaku istri pertama dan Sw sebagai calon istri kedua; Asli surat pernyataan termohon yang telah bersedia untuk dimadu dan memberi izin kepada pemohon untuk berpoligami dengan seorang perempuan bernama Sw; Asli surat keterangan penghasilan pemohon; dan asli surat keterangan pemohon dan termohon tentang rincian harta bersama yang diperoleh selama pemohon dengan termohon membina rumah tangga.

Berdasarkan keterangan pemohon, termohon dan calon istri pemohon yang kedua serta bukti-bukti yang diajukan oleh pemohon dalam persidangan baik bukti surat dan saksisaksinya, maka majelis hakim dapat menemukan fakta-fakta hukum; Bahwa pemohon dengan termohon adalah suami istri sah yang telah menikah pada tahun 1989 dan telah mempunyai anak tiga orang; Bahwa rumah tangga pemohon dengan termohon selama ini berjalan dengan rukun dan harmonis; Bahwa pemohon akan menikah lagi dengan seorang perempuan yang bernama $\mathrm{Sw}$ status janda telah bercerai dengan suaminya dan telah mempunyai anak satu orang; Bahwa alasan pemohon untuk menikah dengan perempuan tersebut adalah karena pemohon telah lama berhubungan dekat dan sudah saling mencintai sehingga tidak mungkin dipisahkan lagi; Bahwa termohon sebagai istri pemohon telah mengizinkan pemohon untuk menikah lagi dengan perempuan tersebut dan bersedia untuk dimadu; dan Bahwa pemohon mempunyai penghasilan tetap sebagai pengusaha konveksi yang dapat mencukupi untuk memenuhi kedua istri dan anak-anaknya nanti.

Pada perkara ini mejlis hakim mengabulkan permohonan Pemohon untuk melakukan poligami. Selain pertimbangan di atas hakim juga menimbang bahwa, berdasarkan Pasal 5 Undang-undang Nomor 1 Tahun 1974 jo Pasal 58 ayat (1) Kompilasi
Hukum Islam dinyatakan bahwa seorang suami akan beristri lebih dari satu orang akan mengajukan permohonan ke pengadilan agama maka untuk dapat mengajukan permohonannya dimaksud, maka harus dipenuhi syarat-syarat; Adanya persetujuan dari istri/istri-istri; Adanya kepastian bahwa suami mampu menjamin keperluan-keperluan hidup istri-istri dan anak-anak mereka; dan Adanya jaminan bahwa suami akan berlaku adil terhada istri-istri dan anak-anak mereka.

Di mana ketiga syarat tersebut sudah dipenuhi oleh Pemohon dengan bukti yang diajukan oleh Pemohon saat persidangan, yaitu surat pernyataan persetutujuan istri untuk dimadu dan memberi izin pada Pemohon, surat pernyataan Pemohon untuk berlaku adil terhadap Termohon selaku istri pertama dan calon istri kedua Pemohon, dan surat keterangan penghasilan Pemohon sebagai seorang pengusaha konveksi yaitu Rp. 4.000.000 (empat juta rupiah)/bulan.

Oleh karena itu, hakim mengabulkan permohonan izin poligami sebab sudah memenuhi syarat pada pasal 55 ayat (2) dan 58 Kompilasi Hukum Islam. Ketika izin istri pertama sudah didapatkan oleh suami dan suami juga bisa menjamin kebutuhan hidup istri-istri dan anak-anaknya maka tidak ada alasan untuk tidak menerima permohonan suami melakukan poligami.

Oleh sebab itu, hakim mengabulkan permohonan Pemohon tersebut karena sudah memenuhi syarat dalam pasal 5 UndangUndang Nomor 1 Tahun 1974 jo Pasal 58 ayat (1) Kompilasi Hukum Islam. Terkait syarat yang terdapat dalam pasal 4 Undang-Undang Nomor 1 Tahun 1974 itu bisa saja dikesampingkan kalau di dalam persidangan sudah cukup bukti untuk menerima permohonan izin poligami tersebut. Jika tidak dikabulkan akan dikhawatirkan antara Pemohon dan calon istrinya akan melakukan perbuatan dosa yang diharamkan oleh Allah, karena keseharian Pemohon sering bersama 
dengan calon istrinya tersebut. ${ }^{23}$

\section{Kasus Perkara No. 0328/Pdt.G/2015/PA.Bk.t}

Adapun yang menjadi alasan Pemohon untuk melakukan poligami karena antara Pemohon dan calon istrinya berkenalan sejak awal Mei tahun 2014 sebagai Terapis dan Pasien dan sering bertemu sehingga terjadi komunikasi dalam rangka konsultasi penyelesaian masalah penunjang kesembuhan. Pemohon juga ingin membahagiakan dan menjadi wali seorang perempuan dan anakanak calon istrinya tersebut. Kemudian calon istri kedua Pemohon mau menerimanya asalkan istri pertama ridho. Istri pertama telah menyatakan keridhoannya terhadap Pemohon untuk menikah lagi. Pemohon juga telah bermusyawarah dengan keluarganya dan mendapat restu, Pemohon telah mempertemukan istrinya dengan calon istrinya dan juga telah mempertemukan keluarga calon istrinya dengan keluarga istrinya dan semuanya menyatakan keridhoan atas maksud Pemohon dengan syarat pernikahan harus dilaksanakan dan dipandang sah secara syari'at dan hukum negara Indonesia. Di samping tujuan di atas, Pemohon juga bermaksud untuk mencegah dan menghindari fitnah dan dosa terhadap diri Pemohon dalam hubungan Pemohon dengan calon istri keduanya.

Selain itu Pemohon juga menyatakan kemampuannya dalam memberi nafkah untuk istri-istri dan anak-anaknya karena Pemohon bekerja sebagai pedagang dan berpenghasilan Rp. 25.000.000,- (dua puluh lima juta rupiah) dan Pemohon juga sanggup berlaku adil. Orang tua dan keluarga calon istrinya menyatakan rela atau tidak keberatan apabila Pemohon menikah dengan calon istrinya dan bersedia menjadi wali nikah, antara Pemohon dan calon istrinya tidak ada larangan melakukan perkawinan baik menurut syari'at

23 Arnel, Hakim Pengadilan Agama Maninjau, Wawancara Pribadi, Minggu, 28 Januari 2018, Pukul 11.00 WIB islam maupun perundang-undangan yang berlaku.

Pada perkara ini majlis hakim menolak permohonan Pemohon untuk melakukan poligami. Adapun yang menjadi pertimbangan hakim adalah: Berdasarkan pasal 4 ayat 2 Undang-Undang Nomor 1 Tahun 1974 explisit verbis menjelaskan tentang alasan-alasan yang dapat dijadikan oleh seorang suami sebagai dasar untuk mengajukan permohonan izin poligami dengan redaksi "pengadilan yang dimaksud dalam ayat (1) pasal ini hanya akan memberikan izin kepada seorang suami yang akan beristri lebih dari seorang apabila:

1) Istri tidak dapat menjalankan kewajibannya sebagai seorang istri

2) Istri mendapat cacat badan atau penyakit lain yang tiak dapat disembuhkan

3) Istri tidak dapat melahirkan

Alasan-alasan yang dimaksud dalam pasal tersebut bersifat alternative fakultatif dan condition sine qua non dalam posita permohonan, artinya apabila salah satu dari alasan-alasan tersebut telah dicantumkan dalam posita permohonan izin poligami, terlepas terbukti atau tidaknya dalam lanjutan pemeriksaan, sudah dipadang cukup sebagai dasar permohonan, namun sebaiknya a contrario apabila posita permohonan izin poligami tidak berdasarkan alasan-alasan atau salah satu alasan yang terdapat dalam pasal tersebut di atas, maka majelis dapat menilai bahwa permohonan Pemohon tidak berdasarkan hukum dan tidak memenuhi syarat formil dari suatu posita permohonan. Karena posita permohonan Pemohon untuk beristri lebih dari seorang tidak sesuai dengan ketentuan yang terdapat dalam pasal 4 ayat (2) UndangUndang Nomor 1 Tahun 1974, maka permohonan Pemohon dapat dinilai tidak berdasarkan hukum dan mengandung cacat formil, dan oleh karenanya permohonan Pemohon a quo harus dinyatakan tidak dapat diterima (Niet Onvankelijke Verklaard/NO).

Putusan perkara ini sudah sesuai dengan aturan Undang-Undang Nomor 1 Tahun 1974 
dan Kompilasi Hukum Islam. Karena tidak terpenuhinya syarat yang ada pada pasal 4 Undang-Undang Nomor 1 Tahun 1974, yaitu:

Pengadilan dimaksud data ayat (1) pasal ini hanya memberikan izin kepada seorang suami yang akan beristri lebih dari seorang apabila:
a. Istri tidak dapat menjalankan kewajibannya sebagai istri
b. Istri mendapat cacat badan atau penyakit yang tidak dapat disembuhkan

c. Istri tidak dapat melahirkan keturunan.

Berdasarkan syarat di atas, Pemohon tidak memenuhi syarat tersebut dalam posita permohonannya. Dalam hal ini hakim menganggap permohonan perkara nomor 0328/Pdt.G/2015/PA.Bkt tidak berdasar hukum atau tidak memenuhi syarat formil dari suatu posita permohonan, artinya tidak ada satupun dalil Pemohon yang menunjukkan terpenuhinya salah satu syarat dibolehkannya seorang suami berpoligami dalam posita sehingga permohonannya tidak diterima (Niet Onvankelijke Verklaard/NO). ${ }^{24}$

Memahami sesuatu dari sudut pandang yang berbeda, akan menghasilkan pemahaman yang berbeda pula dan hal itu wajar dalam sebuah kajian hukum. Begitupun hakim Pengadilan Agama dalam mengabulkan atau tidak menerima permohonan izin poligami. Adalah sebuah kesepakatan bahwa putusan hakim baik yang mengabulkan atau yang tidak menerima, secara normative yuridis dibenarkan berdasarkan adagium res judikata pro veritate babetur yaitu putusan hakim harus dianggap benar, karena hakim dianggap mengetahui tentang hukumya sebagaimana adagium ius curianovit. ${ }^{25}$

Menurut hemat penulis, hakim seharusnya tidak mengabulkan perkara nomor 081/Pdt.G/2013/PA.Bkt dan perkara nomor

24 Afrizal, Hakim Pengadilan Agama Koto Baru Solok, Wawancara, Sabtu, 27 Januari 2018, Pukul 19.00 WIB

25 Sutopo, Istilah dan Adagium Hukum, (Semarang: YPPHIM Kantor Perwakilan Jawa Tengah, 2001), 25
0328/Pdt.G/2015/PA.Bkt. Karena Pemohon dalam permohonannya hanya memenuhi syarat kumulatif saja, sedangkan syarat alternatif tidak terpenuhi sebagaimana dalam pasal 4 ayat (2) Undang-Undang Nomor 1 Tahun 1974 tentang Perkawinan, yaitu:

1) Istri tidak dapat menjalankan kewajibannya sebagai seorang istri

2) Istri mendapat cacat badan atau penyakit yang tidak dapat disembuhkan

3) Istri tidak dapat melahirkan keturunan Sedangkan yang menjadi syarat kumulatif tercantum dalam pasal 5 dalam Undang-Undang Nomor 1 Tahun 1974, yaitu:

1) Adanya persetujuan istri

2) Adanya kepastian bahwa suami mampu menjamin keperluan hidup istri dan anakanaknya

3) Ada jaminan bahwa suami mampu berlaku adil terhadap istri-istri dan anakanaknya

Dalam putusannya hakim berbeda dalam menjadikan bahan pertimbangan terhadap putusan kedua perkara tersebut. Pada perkara nomor 081/Pdt.G/2013/PA.Bkt majelis hakim mengabulkan permohonannya dengan alasan telah terpenuhinya syarat yang dicantumkan dalam Undang-Undang Nomor 1 Tahun 1974 dan juga mempertimbangkan kemaslahatan suami. Jika permohonannya ditolak kemungkinan besar Pemohon dan calon istrinya melakukan perbuatan yang dilarang oleh Allah sedangkan keinginan keduanya sangat besar untuk menikah.

Pada perkara nomor 0328/Pdt.G/2015/Pa.Bkt, hakim me-NO perkara tersebut atau tidak dapat diterima dengan alasan syarat alternatif tidak terpenuhi, sehingga permohonannya tidak memenuhi syarat formil karena tidak ada alasan hukum. Dalam hal ini berarti hakim hanya melihat syarat formilnya saja dan tidak melihat pokok perkaranya dan hakim melihat nasib si istri yang akan merasa terzalimi jika suaminya menikah lagi, padahal istri tidak termasuk ke dalam kategori yang terdapat dalam pasal 4 Undang-Undang Nomor 1 Tahun 1974. 
Jadi, seharusnya putusan hakim tidak berbeda dalam memutuskan kedua perkara tersebut. Jika perkara 081/Pdt.G/2013/PA.Bkt diterima maka begitu juga dengan perkara nomor 0328/Pdt.G/2015/PA.Bkt. Karena syarat alternatif sama-sama tidak terpenuhi.

Namun, setelah penulis melakukan wawancara dengan hakim yang memutuskan kedua perkara tersebut, penulis mendapat kejelasan bahwa pertimbangan hakim berbeda dalam memutuskan suatu perkara yang sama.

$$
\text { Mengenai perkara nomor }
$$
0328/Pdt.G/2015/PA.Bkt yang ditolak oleh hakim karena tidak memenuhi syarat alternatif untuk bisa mengajukan izin poligami sudah sesuai dengan Undang-Undang dan ketentuan beracara di Pengadilan Agama.

Ketetuan tersebut tercantum dalam Buku II Pedoman Pelaksanaan Tugas dan Administrasi Peradilan Agama, yaitu dimana alasan poligami yang diatur dalam Pasal 4 ayat (2) Undang-Undang Nomor 1 Tahun 1974 bersifat fakultatif, maksudnya bila salah satu persyaratan tersebut dapat dibuktikan, pengadilan /mahkamah syar'iyah dapat memberi izin poligami. Karena tidak terpenuhinya alasan untuk melakukan poligami oleh Pemohon, sehingga dalam permohonannya Pemohon juga tidak mempunyai alasan hukum untuk berpoligami, lalu hakim memutuskan untuk me-NO perkara tersebut.

Menurut penulis, hakim seharusnya tetap menerima perkara tersebut terlepas ditolak atau dikabulkannya permohonan itu tergantung saat proses pembuktian di persidangan. Kalau memang pemohon tidak bisa membuktikan terkait dengan apa yang sudah didalilkan dalam permohonannya atau Pemohon memang tidak memenuhi syarat untuk melakukan poligami barulah hakim dapat menolak permohonan tersebut. Padahal Pemohon sudah mendapatkan izin dari istrinya untuk menikah lagi dan dia mampu untuk berlaku adil, begitu juga dengan syarat mampu secara materi, karena Pemohon mempunyai pengahsilan Rp. 25.000.000,-/bulan (dua puluh lima juta rupiah). Jadi semua syarat kumulatif dalam Pasal 5 Undang-Undang Nomor 1 Tahun 1974 sudah terpenuhi oleh Pemohon.

Namun, hakim menganggap bahwa permohonan pemohon tidak memenuhi syarat formil yaitu tidak ada alasan hukum untuk berpoligami, khususnya yang berhubungan dengan syarat alternatif pada pasal 4 UndangUndang Nomor 1 Tahun 1974. Sedangkan dalam permohonannya Pemohon memiliki dasar, yaitu antara Pemohon dan calon istrinya sudah saling mengenal sejak tahun 2014 dengan hubungan terapis dan pasien. Sehingga antara mereka sering terjadi komunikasi dan untuk menghindari fitnah itulah Pemohon ingin adanya hubungan yang resmi antara Pemohon dan pasiennya. Selain itu Pemohon juga ingin membahagiakan calon istrinya dan menjadi wali dari anak perempuan wanita tersebut. Alasan hakim mengatakan bahwa permohonan Pemohon tidak memenuhi syarat formil untuk diterima, sedangkan menurut penulis sudah terpenuhi, karena dalam permohonannya Pemohon sudah mencamtumkan posita dan petitum yang begitu jelas. Kecuali jika Pemohon tidak mencamtumkan posita terkait alasan yang menyebabkannya melakukan poligami atau antara posita dan petitum tidak saling mendukung tidak masalah hakim memiliki alasan tidak menerima perkara ini.

Dengan demikian, setidaknya hakim tetap menerima permohonan Pemohon untuk dilanjutkan dengan pemeriksaan alat-alat bukti di persidangan. Pada saat itulah nantinya hakim bisa menilai apakah Pemohon memang sanggup untuk berlaku berpoligami atau tidak. Bukan tidak menerima (Niet onvankelijke verklaard/NO) perkaranya sebelum diperiksa.

$$
\text { Sedangkan }
$$

perkara 081/Pdt.G/2013/PA.Bkt yang dikabulkan oleh hakim, tentu mempunyai berbagai macam 
pertimbangan hukum. Walaupun tidak sesuai dengan aturan yang ada, namun dalam prakteknya hakim juga bebas berpendapat/berijtihad dan hasil ijtihadnya tidak boleh disalahkan, dan hal tersebut dibenarkan sesuai dengan kaidah hukum, "Apa yang telah diputus oleh hakim, maka harus dianggap benar."

Di antara pertimbangan hakim mengabulkan permohonan tersebut terkait dengan pasal 55 ayat (2) KHI, di mana dinyatakan bahwa syarat utama untuk mendapat izin poligami adalah adil. Pemohon pun dalam persidangan sudah mengajukan pernyataan dan kesanggupannya untuk berbuat adil di antara istri-istrinya, jadi syarat utama sudah dipenuhi oleh Pemohon.

Selanjutnya, izin istri yang tertuang dalam pasal 5 Undang-Undang Nomor 1 Tahun 1974 Jo pasal 58 ayat (1) Kompilasi Hukum Islam juga sudah terpenuhi oleh Pemohon. Begitu juga saat proses persidangan istri Pemohon sudah menyatakan kesediaannya untuk dimadu.

Saat pemeriksaan dalam persidangan hakim melihat hubungan antara Pemohon dan calon istrinya sudah sangat dekat. Seandainya hakim tidak mengabulkan izin poligami dari pemohon, maka akan menimbulkan kemudharatan, karena keinginan Pemohon dan calon istrinya sudah sangat kuat untuk menikah. Jika ditolak permohonannya, besar kemungkinan mereka akan terjerumus kepada perbuatan yang karena dalam kesehariannya antara pemohon dan calon istrinya sering bertemu. Dengan dikabulkannya permohonan tersebut oleh majelis hakim, maka dapat menghidari pemohon dan calon istrinya dari perbuatan maksiat.

Sudah jelas bahwa dampak positif dari pertimbangan hakim mengabulkan permohonan tersebut adalah pemohon dan calon istrinya terbebas dari kemungkinan berbuat zina, dan suami dapat membahagiakan calon istrinya dan anak tirinya kelak yang merupakan anak yatim. Untuk dampak negatifnya pun tidak ditemukan tentang dikabulkannya permohonan tersebut. Hal ini sesuai dengan qawa'id fiqhiyyah yang menjelaskan bahwa "Menolak kerusakan lebih diutamakan daripada memperoleh manfaat atau maslahah."

Untuk mencegah ke-mudharat-an yang akan ditimbulkan di kemudian hari, karena dalam kesehariannya Pemohon dan calon istrinya sering bertemu. Sehingga hakim berijtihad dan hal itu dibolehkan saja selama mengandung kemaslahatan dan tidak ada pihak yang merasa dirugikan. Suami tidak rugi karena permohonannya dikabulkan, begitu juga dengan istri yang sudah menyatakan kesediaannya untuk dimadu.

Dari penjelasan hakim terkait putusan perkara 081/Pdt.G/2013/PA.Bkt penulis dapat memahami bahwa hakim bisa saja keluar dari ketentuan yang ada ketika memutuskan suatu perkara, jika hal itu memang mengandung manfaat. Jadi, dengan dikabulkannya permohonan pemohon sudah merupakan putusan yang tepat karena suami mampu untuk berpoligami dan izin istri sudah didapatkan sehingga tidak ada halangan untuk suami menikah lagi kedua kalinya.

\section{KESIMPULAN}

Dalam memutuskan permohonan izin poligami hakim mengambil dasar dalam Undang-Undang Nomor 1 Tahun 1974 dan juga Kompilasi Hukum Islam. Hakim tidak mutlak hanya mengambil dasar pada UndangUndang Nomor 1 Tahun 1974 saja, tetapi juga dengan mengambil ketentuan yang ada dalam Kompilasi Hukum Islam terkait dengan syarat izin poligami tersebut. Selain itu hakim juga bebas berpendapat di luar ketentuan kedua aturan tersebut, karena pada hakikatnya hakim itu juga pembuat Undang-Undang, bukan saja sebagai corong Undang-Undang.

Landasan hukum yang digunakan hakim dalam putusan Nomor 081/Pdt.G/2013/PA.Bkt tentang izin poligami di Pengadilan Agama Bukittinggi 
adalah pasal 4 ayat (1) Undang-Undang Nomor 1 Tahun 1974 serta pasal 55 ayat (2) dan pasal 56 ayat (1) dan (2) Kompilasi Hukum Islam, serta menimbang pasal 5 Undang-undang Nomor 1 Tahun 1974 jo. Pasal 58 ayat (1) KHI, tanpa mempertimbangkan pasal 4 ayat (2) UndangUndang Nomor 1 Tahun 1974 jo. Pasal 57 KHI. Selain itu, hakim juga mempertimbangkan kemudharatan yang akan terjadi jika permohonan tersebut tidak dikabulkan. Sedangkan putusan nomor 0328/Pdt.G/PA.Bkt masih perkara izin poligami lebih mempertimbangkan pasal 4 ayat (2) Undang-Undang Nomor 1 Tahun 1974 terkait dengan syarat alternatif izin poligami sebelum masuk atau memeriksa pokok perkara. Sehingga hakim tidak menerima (NO) permohonan tersebut karena syarat alternatif tidak terpenuhi. 


\section{DAFTAR KEPUSTAKAAN}

Amir Nuruddin dan Azhari Akmal Tarigan, Hukum Perdata Islam di Indonesia, Jakarta: Kencana, 2004.

Beni Ahmad Saebani, Fiqh Munakahat 2, Bandung: CV Pustaka Setia, 2001.

Undang-Undang Republik Indonesia Nomor 1 Tabun 1974 tentang Perkawinan dan Kompilasi Hukum Islam, Cetakan I, Jakarta: Grahamedia Press, 2014.

Amir Nuruddin dan Azhari Akmal Tarigan, Hukum Perdata Islam di Indonesia, Jakarta: Kencana, 2004.

Sumardi Suryabrata, Metodologi Penelitian, Jakarta: PT Raja Grafindo Persada, Cetakan Ke-11, 1998.

Mahmud, Metode Penelitian Pendidikan, Bandung: Pustaka Setia, 2011.

Karim Ilmi Farhat Ahmad, Ta'addu az-Zaujat fi al-Adyan, Dar al-Afaq al-'Arabiyyah, 2007.

Abdul Rahman Ghozali, Fiqh Munakahat, Jakarta: Kencana, 2010.

A. Rahman I. Doi, Penjelasan Lengkap Hukum-Hukum Allah (Syari'ab), Jakarta: Rajawali Pers, 2002.

Slamet Abidin dan Aminuddin, Fiqh Munakahat, Bandung: CV. Pustaka Setia, 1999.

Yahya Harahap, Hukum Perkawinan Nasional, Medan: Zahir Trading Co Medan, 1975.

Undang-Undang Republik Indonesia Nomor 1 Tabun 1974 tentang Perkawinan dan Kompilasi Hukum Islam, Cetakan I, Jakarta: Grahamedia Press, 2014.

Ahmad Rafiq, Hukum Islam di Indonesia, Jakarta: Rajawali Pers. 1998.

Khairuddin Nasution, Status Wanita di Asia Tenggara; Studi terbadap Perundang-undangan Perkawinan Muslim Kontemporer di Indonesia dan Malaysia, Jakarta: INIS, 2002.

Sutopo, Istilah dan Adagium Hukum, Semarang: YPPHIM Kantor Perwakilan Jawa Tengah, 2001. 